\title{
DIGITAL ECONOMY - BASIC ASPECTS AND THE CASE OF SERBIA
}

\author{
Žarko Đorić ${ }^{1}$
}

\begin{abstract}
The global economy, strong competition, changing the nature of the workforce and consumer sophistication have influenced the need to transform the traditional economy into a digital economy, as a new phenomenon that permeates almost all economic and social processes in one society. The aim of the research is to point out the nature and characteristics of the digital economy, as well as its achieved level of development in the Republic of Serbia. The digital economy, showing its global nature, "leaked" to us, and the very process of digitization by the government was set as one of the three pillars of Serbia's development (in addition to economic growth and education). Using case-study method we found that Serbia is still very far from a massive digital lifestyle. Engaging in an ambitious regulatory reform process in the field of telecommunications: all digital services, applications and content depend on the availability of fast and secure infrastructure.
\end{abstract}

Keywords: globalization, digital economy, information technology, Serbia

\section{INTRODUCTION}

The "digital economy" (network economy, internet economy, new economy, or the web economy) is all economic activity mediated by software and enabled by telecoms infrastructure. Although there is no single definition of digital economy, all efforts to define it are precisely sustainable economic growth, intensive integration of information and communication technologies in all areas of the economy and society, and significant changes resulting from supply and demand. The digital economy is creating an economic revolution, which has been marked by great economic performance and the longest period of continuous economic expansion so far.

The primary objective of the paper is to examine the basic features of the digital economy and its economic effects. Likewise, it will be about the state and challenges of digital transformation in Serbia, which, by the way, is among the moderate innovators with under-performance compared to EU-28 countries. As a rule, Serbia lags behind the most developed countries, at least when it comes to the impact of the digital economy on the overall economic flows in the country. It is encouraging, however, that things slowly but surely are moving forward, bearing in mind, for example, the progress made in the categories of Internet use and digital public services. However, on the other hand, our country does not currently have a comprehensive digital skills strategy, but it is currently

1e-mail: zdjoric82@gmail.com

Vol. 22, бpoj 2/2020, cmp. 73-96 
addressing this issue in many strategic documents. To make indices of the digital economy showed positive results, ie in order to develop the digital market, regulatory frameworks are needed. In the coming period, the following will be important, among other things: strengthening digital skills education for all ages, implementation of Industry 4.0 concepts in selected industries, improving the regulatory framework to encourage innovation and investment in the context of the EU digital single market, encouraging the development of research and innovation in digital technologies, creating new business models for small and medium-sized enterprises, and developing gigabit networks as the basic infrastructure of the Internet of Things. An important stage in the realization of the global nature of information - telecommunication technologies and the development of the digital economy in the coming period will be the realization of the so - called. digital equality and overcoming differences in the relationship between developed countries - countries in transition and development, large companies - small companies, urban and urban centers - rural periphery. The inclusion of small and medium enterprises is also crucial for the continuation of economic development of the economy. The maximum utilization of the potential of digital economy growth can be achieved by investing in ICT infrastructure, for example for storing data on the Internet and using large amounts of data, as well as in research and innovation aimed at stimulating industrial competitiveness. It also includes better public services and improved digital skills of citizens - in short, it is a "inclusive society" (European Union, 2015, p. 5).

The paper is divided into three main parts. The first two parts are theoretical and talk about the key aspects of the digital economy, while the third part lists and describes the indices of the digital economy, and describes the position of Serbia according to Digital Economy and Society Index (DESI index), Global Innovation Index 2018 (GII index), Global Competitiveness Index 4.0 and Network Readiness Index (NRI).

\section{GENERAL CONTEXT OF THE DIGITAL ECONOMY}

Digital economy is an economy based on digital technologies and the predominant use of information technology hardware, software, applications and telecommunications in all areas of the economy, including internal activities of organizations (companies, states, associations, non-profit organizations, etc.), then external activities (various transactions) between the organizations themselves, between organizations and individuals, as well as individuals with each other (individuals both as consumers and as citizens). It is about the 
convergence of computer technology and telecommunications via the Internet.

The digital economy is the modern way in which they are used information technology, and especially the Internet. It led to transition from an industrial economy to an economy that characterized by information, intangibles, invisible values, services and a new form of institutional organization forms (see: Figure 1). According to figure 1 it is obviously that digital economy includes a key digital sector, as well as a wider range of extensive digital activities, some of which do not necessarily have to be part of the digital economy.

Figure 1.: Scoping the digital economy

Broad Scope: Digitalised Economy

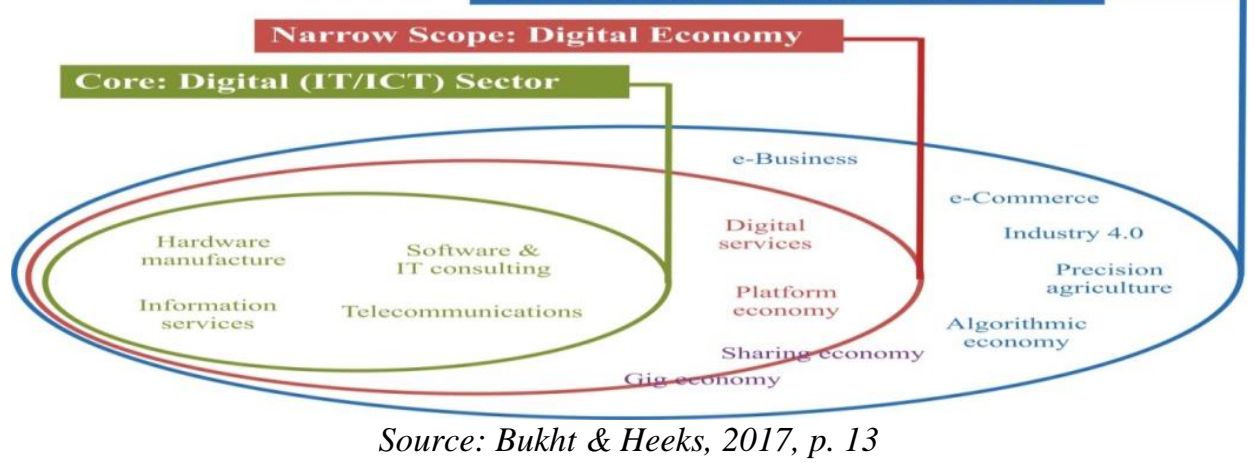

Much has been written about the digital economy, as a current and attractive topic, as evidenced by numerous empirical and theoretical papers in which this phenomenon is highlighted from different aspects (see for example: Mărcuţ, 2017; Zysman \& Kenney, 2018; Schallmo \& Williams, 2018; OECD, 2016; Abraham et al., 2017; Kupriyanovskiy et al., 2016; Van Ark, 2016; WEF, 2015; Mayer, 2018; Bukht \& Heeks, 2018; Goldfarb \& Tucker, 2019; Guo et al., 2017; Devezas et al., 2017; Afonasova et al., 2018; OECD, 2015).

\section{IMPORTANCE AND ADVANTAGES OF DIGITAL ECONOMY}

With the help of the digital economy, radical changes are taking place in the perception of business resources from the physical tangible to the digital, electronic and intangible. The digital economy is based on the intensive application of information and communication technology in business, ie on the intensive application of electronic business methods that relate not only to technological features, but also to economic activities, processes, structures, models, which ultimately means radically 
changing and how to create economic value. The digital economy is based on knowledge, innovation and digital information. The essence of the digital economy consists of knowledge, the Internet and technologies that help manage and develop businesses: business entities, public administration and citizens. The obvious advantages of digital technologies for a given economy are summarized in Table 1.

Table 1.: How the three mechanisms apply to businesses, people, and governments

\begin{tabular}{|c|c|c|c|}
\hline & \multicolumn{3}{|c|}{ Digital Technologies } \\
\cline { 2 - 4 } & INCLUSION & EFFICIENCY & INNOVATION \\
\hline BUSINESSES & Trade & Capital utilization & Competition \\
\hline PEOPLE & Job opportunities & Labor productivity & Consumer welfare \\
\hline GOVERNMENTS & Participation & Public sector capability & Voice \\
\hline
\end{tabular}

According to Bloch \& Segev (1996), the impact of digital economy on business (microeconomics) can be divided into three major categories (see: Unold, 2003, p. 47): (1) improving direct marketing (product promotion, new sales channels, direct savings, customer service, brand or corporate image, customization, advertising, ordering systems, markets, reduced cycle time); (2) transforming organizations - rapid progress in digital economy forces companies to adapt quickly to the new technologies and offers them an opportunity to experiment with new products, services and business models and (3) redefining organizations completely new products are created and existing ones are customized. The digital economy is "green" and promotes wider principles of sustainable development. It is expected that its impact on the environment will be more subtle and more positive than it is with traditional industries (Digital Serbia, 2017). There is opportunities for creating strategic synergies between digital economy and green economy strategies through: green ICT products and services; smart energy grids, transportation infrastructures, buildings and production processes in all economic sectors; smart systems for monitoring the environment and managing natural resources; dematerialization of products and services in consumer and business marketplaces, and in government and public services; transformation of organizational structures and work practices throughout the economy and society; and transformation of values, attitudes and behaviour of individuals, as consumers and citizens ${ }^{2}$.

\footnotetext{
2 See: The Digital Economy and the Green Economy: Opportunities for strategic synergies, An IISD Commentary, July 2010, p. 1
} 
However, the digital economy also has its dark side. Risks brought about by the development of the digital economy: instability, unemployment (job creation may be slower than job destruction during a transition period), lining, threatening security and privacy and crime.

\section{DIGITAL ECONOMY IN SERBIA: CHALLENGES, OPPORTUNITIES AND READYNESSES OF ICT TECHNOLOGY APLICATION}

Serbia rightly wants to accelerate digitalization and to develop the digital economy and the first steps are recognizable. However, it is sometimes difficult for Serbian citizens to understand what the benefits of the digital economy are, and there is fear, disbelief and aversion to digitizing of our daily lives and businesses. Building a digital economy based on innovation and knowledge (which changes the structure of the economy) is imposed as an obligation if Serbia wants to keep up with developed countries and modern flows of economic development. Serbia need digital economy because of:

Table 2.: Importance of digital economy for Serbia country

\begin{tabular}{|c|c|c|}
\hline $\begin{array}{l}\text { ICT as a part of } \\
\text { solution }\end{array}$ & $\begin{array}{c}\text { Serbia suffers } \\
\text { from these key } \\
\text { barriers: }\end{array}$ & $\begin{array}{l}\text { Policy attention } \\
\text { should be on: }\end{array}$ \\
\hline $\begin{array}{l}\text { Serbia needs new source of } \\
\text { growth }\end{array}$ & Lack of policy attention & $\begin{array}{l}\text { ICT should be a key } \\
\text { priority for Serbia }\end{array}$ \\
\hline $\begin{array}{l}\text { A severe lack of } \\
\text { productivity, lack of } \\
\text { competition and } \\
\text { growth }\end{array}$ & $\begin{array}{l}\text { Businesses find it } \\
\text { difficult to operate in } \\
\text { the new ICT based } \\
\text { manner, markets are } \\
\text { closed and monopolized }\end{array}$ & $\begin{array}{l}\text { ICT transformation of } \\
\text { companies and } \\
\text { liberalization of markets }\end{array}$ \\
\hline Low level of innovation & $\begin{array}{l}\text { Decreasing R\&D } \\
\text { activities, number of } \\
\text { researchers, brain } \\
\text { drain, }\end{array}$ & $\begin{array}{l}\text { Increase investment in } \\
\text { education, research and } \\
\text { development especially } \\
\text { in ICT }\end{array}$ \\
\hline $\begin{array}{l}\text { High unemployment } \\
\text { levels }\end{array}$ & $\begin{array}{l}\text { Jobs lost in the process } \\
\text { of privatization, young } \\
\text { unemployment }\end{array}$ & $\begin{array}{l}\text { Active labor market } \\
\text { policies, skills, life-long } \\
\text { learning and education }\end{array}$ \\
\hline $\begin{array}{l}\text { Inefficient and expensive } \\
\text { state }\end{array}$ & $\begin{array}{l}\text { Low productivity of } \\
\text { public sector }\end{array}$ & $\begin{array}{l}\text { Support e-government } \\
\text { development }\end{array}$ \\
\hline $\begin{array}{l}\text { Transforming the Serbian } \\
\text { economy to a digital } \\
\text { economy }\end{array}$ & $\begin{array}{l}\text { Lack of awareness } \\
\text { about ICT potentials } \\
\text { and risks }\end{array}$ & $\begin{array}{l}\text { Create ICT supportive } \\
\text { environment }\end{array}$ \\
\hline
\end{tabular}

Source: Authors compilation

Despite the difficulty of tracking the impact of innovation and trends in the digital economy, they exist many researches and indices of digital development, ie maturity that can give insight into effects of 
digitization. The following paper describes some of the important indexes that testify to the position of our country in the field of digital economy.

Based on the Digital Economy and Society Index (DESI index) (first introduced in 2014), Eurostat measures the degree of digitization of EU member states (see: Figure 2). The Digital Economy and Society Index (DESI) is a composite index that summarises relevant indicators on Europe's digital performance and tracks the evolution of EU member states in digital competitiveness. The higher the value, the better the country is in the field of digitization. The DESI index is an indicator of economic and social digitization, and is calculated as the weighted average of the five main DESI categories: 1. Connectivity (25\%) - Fixed broadband, mobile broadband, fast and ultrafast broadband and broadband prices - The connectivity indicator measures the implementation of broadband infrastructure and its quality. Access to high-speed and ultrafast services with broadband access is a necessary condition for competitiveness; 2. Human capital (25\%) - Basic skills and internet use, advanced skills and development - Human Capital / Digital Skills Indicator - measures the skills needed to take advantage of the opportunities offered by digitalisation; 3 . Use of internet service $(15 \%)$ Citizens' use of content, communication and online transactions - Internet service usage indicator - includes various online activities, such as consumption of online content (videos, music, games, etc.), video calls, as well as online shopping and banking; 4. Integration of digital technology (20\%) - Business digitisation and e-commerce - Digital technology integration indicator - measures the digitalization of enterprises and ecommerce. By adopting digital technologies, companies can increase efficiency, reduce costs and better engage customers and business partners. Furthermore, the Internet as a point of sale offers access to a wider market and potential growth and 5. Digital public services (15\%) eGovernment and eHealth - Public Services Digitization Indicator measures the digitization of public services with an emphasis on egovernment and e-health. Modernization and digitization of public services can lead to increased efficiency for both public administration, but also for citizens and companies. The DESI aims to help EU countries identify areas requiring priority investments and action, in order to bring all EU countries at the same level of digitisation. This is an essential element to the establishment of a truly Digital Single Market - one of the top priorities of the Commission. Over the past year, all EU countries improved their digital performance. Finland, Sweden, the Netherlands, and Denmark scored the highest ratings in DESI 2019 and are among the global leaders in digitalisation. These countries are followed by the United Kingdom, Luxembourg, Ireland, Estonia, and Belgium. Some 
other countries however still have a long way to go, and the EU as a whole needs improvement to be able to compete on the global stage. For us, the position of Croatia as a member of the European Union is relevant ${ }^{3}$, and it is ranked based on the DESI score in cluster of low performing countries. In the digitization process, measured by the DESI index, Croatia is most lagging behind in the category of connectivity, which mainly refers to coverage of broadband internet, the density of fixed and mobile connections in relation to the number of inhabitants, the prices of such internet to purchasing power parity, etc.

Figure 2.: Digital Economy and Society Index (DESI), 2019 ranking

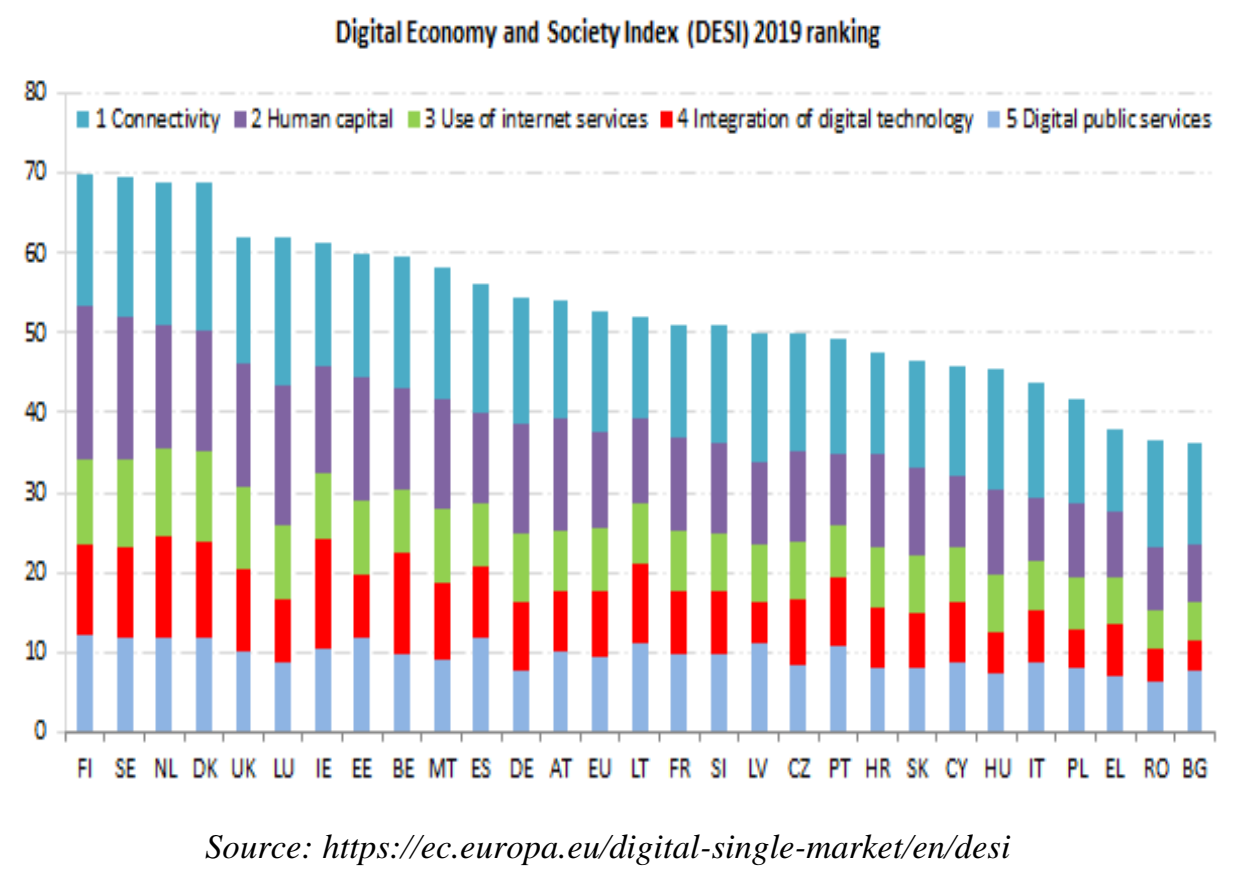

The International Digital Economy and Society Index (I-DESI) (see: Figure 3) mirrors and extends the EU28 Digital Economy and Society Index by utilising 24 datasets to enable trend analysis and comparison of the digital performance of 45 countries. The DESI is a composite index that benchmarks relevant indicators on digital performance and tracks the evolution of the EU as a whole and its member states in digital competitiveness.

\footnotetext{
${ }^{3}$ Otherwise, the situation in the digital economy in Croatia is important for us, because its economy is comparable to the economy of the Republic of Serbia and that Croatia is the youngest member of the EU.
} 
Figure 3.: International DESI (I-DESI), 2018

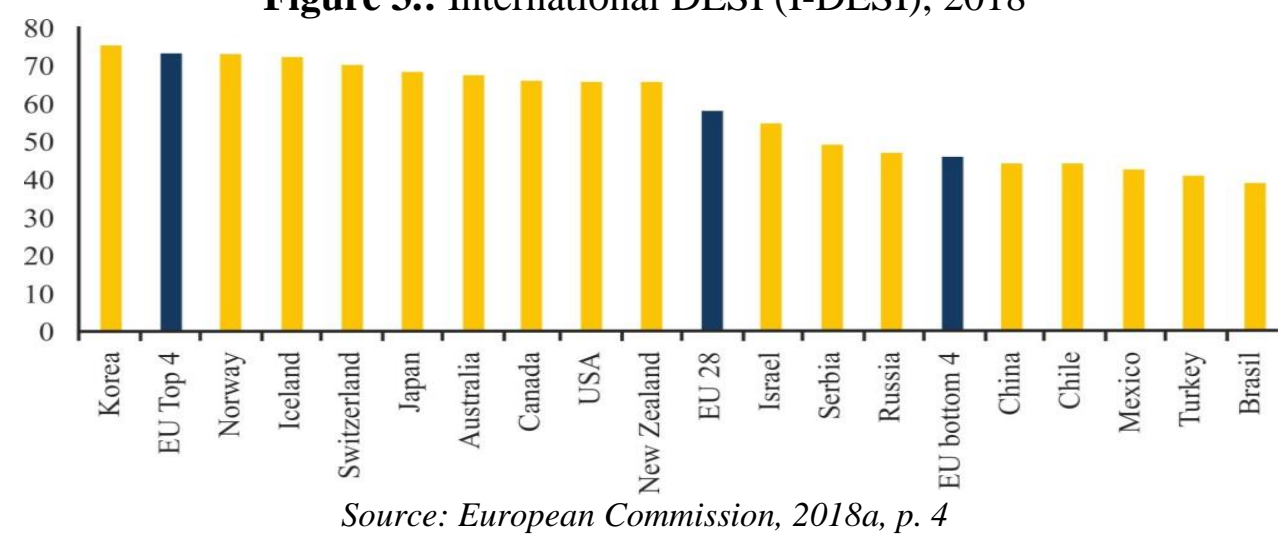

The 2018 I-DESI utilises datasets over a four year time period from 2013 to 2016 to provide trend analysis. It brings together a set of relevant indicators similar to the current EU28 DESI digital policy mix. IDESI combines 24 indicators and uses a weighting system to rank each country based on its digital performance with the aim to benchmarking the development of the digital economy and society. It measures performance in five dimensions or policy areas: connectivity, human capital (digital skills), use of Internet by citizens, integration of technology and digital public services. Indeed Denmark was the leading country in the I-DESI index. EU28 Member States perform best, relative to the 17 non-EU countries, in the Connectivity dimension (examining the deployment and take-up of fixed and mobile broadband) and in the Citizen Use of the Internet dimension. Table 3 compares the aggregate performance of EU top 4 Member States avg. with Serbia country across all five I-DESI dimensions for 2016, where it is obvious that the backwardness of our country is enormous in all dimensions.

The low value of DESI 2018 for Serbia is predominantly influenced by the lack of fixed broadband access, ie the increase of DESI index can be achieved if the category of Connectivity is improved, ie. if high speed fixed networks are provided. An important segment of the development of broadband access is mobile broadband access which enables access to the Internet with mobile devices and laptops regardless of the location where the user is located. With the development of broadband access, it is necessary to achieve that the prices and conditions of Internet access in the Republic of Serbia are close to the EU average for all flow speeds. 
Table 3.: I-DESI dimension for Serbia in comparison with EU top 4

\begin{tabular}{|c|c|c|c|c|c|}
\hline $\begin{array}{c}\text { normalised } \\
\text { performance } \\
\text { scores for I- } \\
\text { DESI in 2016 }\end{array}$ & $\begin{array}{c}\text { Average } \\
\text { performance } \\
\text { scores for the } \\
\text { connectivity } \\
\text { dimension }\end{array}$ & $\begin{array}{c}\text { Average } \\
\text { performance } \\
\text { scores for the } \\
\text { human capital } \\
\text { dimension }\end{array}$ & $\begin{array}{c}\text { Average } \\
\text { performance } \\
\text { scores for the } \\
\text { citizen } \\
\text { internet use } \\
\text { dimension }\end{array}$ & $\begin{array}{c}\text { Average } \\
\text { scores for the } \\
\text { business } \\
\text { technology } \\
\text { integration } \\
\text { dimension }\end{array}$ & $\begin{array}{c}\text { Average } \\
\text { performance } \\
\text { scores for the } \\
\text { public services } \\
\text { dimension }\end{array}$ \\
\hline $\begin{array}{c}\text { Serbia } \\
\mathbf{4 9 . 6}\end{array}$ & $\begin{array}{c}\text { Serbia } \\
\mathbf{5 2 . 3}\end{array}$ & $\begin{array}{c}\text { Serbia } \\
\mathbf{4 4 . 4}\end{array}$ & $\begin{array}{c}\text { Serbia } \\
\mathbf{4 9 . 6}\end{array}$ & Serbia & $\mathbf{4 4 . 3}$ \\
\hline $\begin{array}{c}\text { normalised } \\
\text { performance } \\
\text { scores for I- } \\
\text { DESI in 2016 }\end{array}$ & & & & & $\mathbf{6 0 . 7}$ \\
\hline $\begin{array}{c}\text { EU Top 4 } \\
\mathbf{7 4 . 0}\end{array}$ & EU Top 4 & EU Top 4 & EU Top 4 & EU Top 4 & EU Top 4 \\
\hline
\end{tabular}

Note: I-DESI includes the same five dimensions as the DESI, but it is built on a slightly different set of indicators due to some of the DESI indicators not being available in nonEU countries. As a result, the I-DESI rankings and scores are slightly different to those of the DESI. The normalisation process scaled data sets (often collected in different ways e.g. percentages, scores of 0 to 1 and scales of 1 to 7 ) into a range from 0 to 1 . For ease of comparison these scores have been converted into a scale of 0 to 100 in this report.

Source: European Commission (2018b). International Digital Economy and Society Index 2018, SMART 2017/0052, FINAL REPORT, European Union, 2018, ISBN 978-9279-85699-0

World Economic Forum in its Readiness for the Future of Production Report 2018 measure Readiness for the Future of Production, where "readiness" is the ability to capitalize on future production opportunities, mitigate risks and challenges, and be resilient and agile in responding to unknown future shocks. The framework has been applied to conduct an analysis of 100 countries and economies, which represent over $96 \%$ of global Manufacturing Value Added (MVA) and over $96 \%$ of global Gross Domestic Product (GDP). The assessment measures readiness for the future of production across two different components: 1. Structure of Production (reflects the complexity and scale of a country's current production base, and countries with a large, more complex Structure of Production today are more ready for the future in that they already have a production base to build upon) and 2. Drivers of Production (as a key enablers that position a country to capitalize on emerging technologies and opportunities in the future of production) (WEF, 2018, p. 5-6). Ranking of Serbia according to this indicator is given in Table 4. Serbia is ranked in Nascent Countries/Economies countries with a limited production base today that exhibit a low level of readiness for the future through weak performance across the Drivers of Production component. 
Table 4.: Readiness for the Future of Production Assessment Results, 2018, Serbia

\begin{tabular}{|c|c|c|c|c|}
\hline Country & \multicolumn{2}{|c|}{ Structure of Production } & \multicolumn{2}{c|}{ Drivers of Production } \\
\hline & Score/10 & Rank & Score/10 & Rank \\
\hline Serbia & 5.18 & 42 & 4.59 & 64 \\
\hline
\end{tabular}

The Global Innovation Index 2018 (GII index) helps to create an environment in which innovation factors are continually evaluated, and it provides a key tool for decision makers and a rich database of detailed metrics for refining innovation policies. For 2018, it provides a key tool of detailed metrics for 126 countries/economies, which represent $90.8 \%$ of the world's population and $96.3 \%$ of the world's GDP (bn PPP \$). Four measures are calculated: the overall GII, the Input and Output SubIndices, and the Innovation Efficiency Ratio. The overall GII index scoreis the simple average of the Input and Output Sub-Index scores. The Innovation Input Sub-Indexis comprised of five input pillars that capture elements of the national economy that enable innovative activities: (1) Institutions (Political environment, Regulatory environment, Business environment), (2) Human capital and research (Education, Tertiarty education, Research \& development), (3) Infrastructure (ICTs, General infrastructure, Ecological sustainability), (4) Market sophistication (Credit, Investment, Trade, competition, \& market scale), and (5) Business sophistication (Knowledge workers, Innovation linkages, Knowledge absorbtion). The Innovation Output Sub-Index provides information about outputs that are the results of innovative activities within the economy. There are two output pillars: (6) Knowledge and technology outputs (Knowledge creation, Knowledge impact, Knowledge difusion) and (7) Creative outputs (Intangible assets, Creative goods and services, Online creativity). The Innovation Efficiency Ratio is the ratio of the Output Sub-Index score over the Input Sub-Index score. It shows how much innovation output a given country is getting for its inputs ${ }^{4}$. Ranking of Serbia according to this indicator is given in Table 5 and 6. In comparison to 2017, Serbia has progressed in 7 places in the GII index. Serbia is best ranked when it comes to infrastructure ( $48^{\text {th }}$ place), and the worst in the Market sophistication (Rank 101) segment, which includes access to loans, investor protection and number of projects funded with venture capital.

\footnotetext{
${ }^{4}$ For GII conceptual framework see: Cornell University, INSEAD \& WIPO (2017): The Global Innovation Index 2017: Innovation Feeding the World, Ithaca, Fontainebleau, and Geneva, p. 11 - 12
} 
Table 5.: Global Innovation Index, 2018 rankings

\begin{tabular}{|l|l|l|l|l|}
\hline Country/Economy & Score $(0-100)$ & Rank & Efficiency Ratio & Rank \\
\hline Serbia & 35.46 & 55 & 0.63 & 57 \\
\hline
\end{tabular}

Source: adapted from Cornell University, INSEAD \& WIPO (2018): The Global

Innovation Index 2018: Energizing the World with Innovation, Ithaca, Fontainebleau, and Geneva, p. xx

Table 6.: GII sub-index rankings and values, Serbia, 2018

\begin{tabular}{|l|l|l|l|}
\hline Country/Economy & $\begin{array}{l}\text { Innovation Input Sub-Index } \\
(\text { Score }(0-100))\end{array}$ & $\begin{array}{l}\text { Innovation Output Sub-Index } \\
(\text { Score (0-100)) }\end{array}$ & \\
\hline Serbia & $43.50($ Rank 56) & $27.42($ Rank 58) & \\
\hline
\end{tabular}

Source: adapted from Cornell University, INSEAD \& WIPO (2018): The Global

Innovation Index 2018: Energizing the World with Innovation, Ithaca, Fontainebleau, and Geneva, p. xxii, xxiv

The World Economic Forum introduced last year the new Global Competitiveness Index 4.0 (GCI 4.0 in 2019), a much-needed new economic compass, building on 40 years of experience of benchmarking the drivers of long-term competitiveness. The index is an annual yardstick for policy-makers to look beyond short-term and reactionary measures and to instead assess their progress against the full set of factors that determine productivity. These are organized into 12 pillars: Institutions; Infrastructure; ICT adoption; Macroeconomic stability; Health; Skills; Product market; Labour market; Financial system; Market size; Business dynamism; and Innovation capability. Table 7 shows the evaluation of factors of global competitiveness of our country for 2019, and the obtained results mean that our country is positioned in middle developed countries that is at the level of previous years and shows that we are standing still while the countries we want to compare ourselves with are implementing reforms faster and making progress (World Economic Forum, 2019).

Table 7. Factors of global competitiveness of Serbia - evaluation for the 2019

\begin{tabular}{|l|l|l|}
\hline \multicolumn{1}{|c|}{ Serbia } & \multicolumn{2}{c|}{ 72nd/141 } \\
\hline Index Component & Score $^{*}$ & Rank/141 \\
\hline 1st pillar: Institutions 0-100 & $52.5 \uparrow$ & 75 \\
\hline 2nd pillar: Infrastructure 0-100 & $73.8 \uparrow$ & 51 \\
\hline 3rd pillar: ICT adoption 0-100 & $52.6 \downarrow$ & 77 \\
\hline $\begin{array}{l}\text { 4th pillar: Macroeconomic } \\
\text { stability 0-100 }\end{array}$ & $75.0=$ & 64 \\
\hline 5th pillar: Health 0-100 & $79.0 \downarrow$ & 76 \\
\hline 6th pillar: Skills 0-100 & $68.2 \uparrow$ & 55 \\
\hline 7th pillar: Product market 0-100 & $54.6 \downarrow$ & 73 \\
\hline 8th pillar: Labour market 0-100 & $62.1 \uparrow$ & 54 \\
\hline 9th pillar: Financial system 0-100 & $57.4 \uparrow$ & 82 \\
\hline 10th pillar: Market size 0-100 & $51.8 \uparrow$ & 74 \\
\hline 11th pillar: Business dynamism 0- & $63.1 \uparrow$ & 54 \\
100 & & \\
\hline
\end{tabular}

Vol. 22, бpoj 2/2020, cmp. 73-96 


\begin{tabular}{|l|c|c|}
\hline $\begin{array}{l}\text { 12th pillar: Innovation capability } \\
0-100\end{array}$ & $40.2 \uparrow$ & 59 \\
\hline
\end{tabular}
Note: Scores are on a 0 to 100 scale, where 100 represents the optimal situation or 'frontier'

Source: WORLD ECONOMIC FORUM (2019). The Global Competitiveness Report 2019. World Economic Forum, Geneva

The Network Readiness Index is a key indicator of how countries are progressing in the digital world. Network Readiness Index (NRI), which provided, for the first time, a holistic framework for assessing the multi-faceted impact of ICT on society and the development of nations. Early on, the NRI identified the three key stakeholders for ICT: individuals/society, businesses, and governments, and included elements of ICT application that were novel for the time - for example, a focus on the political environment and quality of regulations. The reasoning behind the pillars and sub-pillars of the redesigned NRI model can be summarized as follows (see: Portulans Institute, 2019):

(A) Technology - Technology is at the heart of the network economy. This pillar therefore seeks to assess the level of technology that is a sine qua non for a country's participation in the global economy. The following three sub-pillars have been identified for that purpose: 1 . Access: The fundamental level of ICT in countries, including on issues of communications infrastructure and affordability, 2. Content: The type of digital technology produced in countries, and the content/applications that can be deployed locally, 3. Future Technologies: The extent to which countries are prepared for the future of the network economy and new technology trends such as artificial intelligence (AI) and Internet of Things (IoT).

(B) People - The availability and level of technology in a country is only of interest insofar as its population and organizations have the access, resources, and skills to use it productively. This pillar is therefore concerned with the application of ICT by people at three levels of analysis: individuals (How individuals use technology and how they leverage their skills to participate in the network economy); businesses (How businesses use ICT and participate in the network economy) and governments (How governments use and invest in ICT for the benefit of the general population).

(C) Governance - A country's network readiness does not take place in a vacuum and is a function of the national context within which people operate. Thus, this pillar seeks to capture how conducive the national environment is for a country's participation in the network economy, based on issues of trust (How safe individuals and firms are in the context of the network economy. This does not only relate to actual crime and 
security, but also to perceptions of safety and privacy); regulation (The extent to which the government promotes participation in the network economy through regulation) and inclusion (The digital divides within countries where governance can address issues such as inequality based on gender, disabilities, and socioeconomic status).

(D) Impact - Ultimately, readiness in the network economy is a means to improve the growth and well-being in society and the economy. This pillar therefore seeks to assess the economic, social, and human impact of participation in the network economy.

Eventually, 62 indicators have been identified to populate these 12 sub-pillars. The Network Readiness Index 2019 ranks a total of 121 economies. The top performer in this year's index is Sweden (score 82.65), which is just ahead of Singapore in 2nd place and the Netherlands in $3 \mathrm{rd}$. In truth, there is not much separating the leading countries in the NRI, as reflected in their overall scores. For instance, the top 5 countries (which also include Norway, 4th, and Switzerland, 5th) are all within a couple of points of each other. Similarly, the other countries that make up the top 10-Denmark, Finland, the United States, Germany, and the United Kingdom - are less than 5 points away from Sweden's top score. Ranking Serbia according to key parameters which are studied in the World Economic Forum report is presented in Table 8. With an average score of 53.65 for Serbia, our country is positioned in the rank of middledeveloped countries according to this index, which indicates the need for further significant improvements.

Table 8.: Factors of global competitiveness of Serbia - evaluation for the

\begin{tabular}{|l|c|c|}
\hline \multicolumn{1}{|c|}{ SERBIA } & $\begin{array}{c}\text { Rank } \\
\text { (out of 121) }\end{array}$ & Score \\
\hline \multicolumn{1}{|c|}{ Network Readiness Index } & $\mathbf{5 2}$ & $\mathbf{5 3 . 6 5}$ \\
\hline A. Technology pillar. & $\mathbf{5 0}$ & $\mathbf{5 0 . 5 4}$ \\
\hline 1st sub-pillar: Access & 51 & 73.79 \\
\hline 2nd sub-pillar: Content sub-pillar: & 39 & 58.26 \\
\hline 3rd & 104 & 19.59 \\
technologies. & & \\
\hline B. People pillar.. & $\mathbf{5 1}$ & $\mathbf{4 6 . 5 3}$ \\
\hline 1st sub-pillar: Individuals & 63 & 55.30 \\
\hline 2nd sub-pillar: Businesses & 45 & 37.20 \\
\hline 3rd sub-pillar: Governments & 56 & 47.09 \\
\hline C. Governance pillar & $\mathbf{6 0}$ & $\mathbf{6 1 . 4 9}$ \\
\hline 1st sub-pillar: Trust & 63 & 56.23 \\
\hline 2nd sub-pillar: Regulation & 68 & 62.44 \\
\hline 3rd sub-pillar: Inclusion & 55 & 65.80 \\
\hline D. Impact pillar & $\mathbf{5 5}$ & $\mathbf{5 6 . 0 3}$ \\
\hline 1st sub-pillar: Economy & 46 & 26.38 \\
\hline 2nd sub-pillar: Quality of life & 69 & 59.56 \\
\hline 3rd sub-pillar: SDG Contribution & 53 & 82.14 \\
\hline Note:SDG = Sustainable Development Goal & \\
\hline
\end{tabular}

Source: Portulans Institute, 2019

Vol. 22, бpoj 2/2020, cmp. 73-96 
In Serbia, the representation of Broadband Internet in households in 2016 was increased (57.8\%) compared to 2010 (27.65\%) (RZS, 2017, p. 396). At the same time, the number of business entities that had an internet connection, which used e-government services in enterprises (2010 - 70.6\%, 2016 - 98.6\%) (RZS, 2017, p. 398), has also increased. However, in general, the Republic of Serbia invests little in IT infrastructure and human resources. Statistical indicators of Serbia also say that it is proportional to the number of inhabitants, the country is in a growing backdrop for Europe and the world, which encourages further growth of the existing large economic gap. The largest number of citizens is on the wrong side of the digital divide and is unable to take advantage of ICT. There is still an high percentage of citizens who have never used the Internet, who do not have an Internet connection or informatically are illiterate, especially persons with disabilities, Roma population, rural population. The obsolescence of certain educational programs is one of the biggest weaknesses in the transition to a digital society, along with insufficient funds allocated by the state for higher education (Mitrović, 2017). Investing in human capital and raising the level of digital literacy, knowledge and skills will ensure the creation of an information society in which everyone will benefit from the benefits of using ICT. When it comes to better use of information and communication technologies in Serbia, the recommendations are also the development and adoption of strategic documents in the field of development of broadband access and digital involvement, conducting continuous, comprehensive research, use and application of ICT in the general and segmented population, establishing a "digital dialogue" between the public administration, the academy, the industry and the civil sector, in order to identify problems and determine the development priorities, as well as the model of the application of domestic law on the Internet. When it comes to tax policy as one of the critical points of progress in terms of digitization, Serbia needs an urgent reform of the tax system to enable tax incentives for digital companies and stimulate entrepreneurship (Digital Serbia, 2017).

Based on the relevant indicators, we can conclude that the digital economy in the Republic of Serbia is not sufficiently developed. It is still in its "installation phase" and productivity effects may occur only once the technology enters the "deployment phase", when the new technological paradigm will have been widely diffused and will have become common practice across organizations, enabling its full potential in terms of economic and business growth, productivity, and profitability. The most important strategic document setting the development trends of digital economy in Serbia is the Strategy for the Development of 
Information Society in the Republic of Serbia up to $2020^{5}$, and, together with the strategy in the field of telecommunications, this strategy forms the Digital Agenda for the Republic of Serbia. According to this Strategy, among others, the engine of information society development consists of: open, accessible to all and quality Internet access and developed ebusiness, including: e-government, e-commerce, e-justice, e-health and eeducation. The development of the information society should be monitored by: (1) inclusion of all citizens of the Republic of Serbia, which especially refers to the inclusion of social groups with special needs, regional development and strengthening local initiatives; (2) developing knowledge and skills related to ICT and strengthening the role of ICT in the education system; (3) constant investment in research and innovation, so that the potentials brought by ICT are recognized, perceived and in the best way used; (4) responses to the challenges posed by ICT, such as: new aspects of security, privacy threats, technological dependence, insufficient interoperability and open issues of intellectual property protection and (5) coordination and cooperation between the public, private and civil sectors (Strategija razvoja informacionog društva u Republici Srbiji do 2020. godine, p. 2020).

The change of the development paradigm in the direction of accepting the concept of the digital economy poses a number of challenges to the economy of Serbia. The issue of digital economy in Serbia is not purely technological or economic. It is also par ex-cellence political issues and one of the key issues and dilemmas of Serbian society. Its development would improve the export and development performance of the country. In Serbia, the regulatory framework for the application of digital technologies must be improved, as well as the construction of an infrastructure that supports increasing the digital competitiveness of businesses (Spalević et al., 2018, p. 29). As part of the digital transformation, Serbia must concentrate on high added value services (science, education, health care, programming, etc.) because of their role of catalyst in dynamic economic growth (Đuričin \& Vuksanović Herceg, 2018, p. 19). Furthermore, a more harmonized approach to digital transformation in the region and integration into the European Digital Single Market is needed. Within the broader EU accession strategy, the European Commission, at a meeting of the Digital Assembly in Sofia, on June 25, 2018, launched the Digital Agenda for the Western Balkans in order to support the transition of the region to the digital economy and

\footnotetext{
${ }^{5}$ see: Strategija razvoja informacionog društva u Republici Srbiji do 2020. godine, Službeni Glasnik Republike Srbije br. 5/2010, 2010, available at: http://paragraf.rs/propisi/strategija_razvoja_informacionog_drustva_u_republici_srbiji.ht $\mathrm{ml}$
} 
enable the benefits of digital transformation, such as economic growth, jobs, better services. The Commission together with Ministers from six Western Balkan partners - Albania, Bosnia and Herzegovina, Kosovo, Montenegro, the former Yugoslav Republic of Macedonia and Serbia will commit to (see: European Commission, 2018c): 1. Investing in broadband connectivity, 2. Increasing cybersecurity, trust and digitalisation of industry, 3. Strengthening the digital economy and society (The Digital Agenda will support the deployment of eGovernment, eProcurement, and eHealth tools and help increase digital skills among citizens) and 4. Boosting research and innovation (The Digital Agenda will help set up national research facilities and develop state-of-art e-infrastructures in the Western Balkans and will integrate them in an emerging digital European Research Area). The European Union has recognized the underdevelopment of ICT in Serbia as a limiting factor for the development of the "information society" on the one hand and the Webdigital economy on the other. The development of digital communication and the information society are a significant factor in increasing national competitiveness and improving the business climate and quality of life of citizens. To this end, the EU sets the following digital "tasks" for economic policy makers in Serbia (Izveštaj Svetske banke, Informacija i komunikacija za razvoj 2009: proširenje dostupnosti i povećanje uticaja, 2009): 1) digitizing telecommunications infrastructure, 2) making the Internet accessible everyone, 3) fast, cheap and secure Internet, 4) broadband Internet access development, 5) Web economy development, 6) digital television introduction, 7) electronic communications equipment industry development, 8) mobile service development, 9) introduction of number portability service and 10) e later access to information and knowledge.

Serbia is lagging behind in creating building blocks for a successful digital economy and industry 4.0. Although eGovernment projects have made possible substantial changes in the functioning of serbian economy, further efforts are needed both at regional and national level in terms of taxation, social systems, labor laws, modernization of education, support for innovation, PPP and social dialogue to prepare for industry 4.0, the economy of exchange and e-business. In the coming period it is necessary organize new strategies as cross-sectoral documents (Strategy of smart specialization, (new) Industrial strategy, Strategy of Digital Competence, etc.) focused on the needs of digital technology, with the focus on investing in artificial intelligence (AI), innovation, digital skills, talent retention and infrastructure. Biggest space for improving the digitization level in our country is recognized in the fields of digitization of industry, social innovations, artificial intelligence, the 
Internet of Things, blocking and "big facts" technologies, as well as cyber security. In addition, the development of advanced digital transport solutions and the development of "smart cities" is important, which should enable easier and cheaper life for people in urban areas. Until now, the digital economy has mostly talked about software firms working for foreign customers and the good payers of the programmer, and therefore, in the upcoming period, more companies are needed that create their products here using technology in different sectors, because in this way, the digital economy includes experts from other professions such as marketing, agriculture, mining, medicine, etc. ${ }^{6}$ "In order to reach the services of intelligent transport systems, the advanced digital solutions in production, smart energy, e-health, smart environmental monitoring and all other smart services, it is important that we also speak globally with one voice on data liberalization, the access to data, data security, data management ..."7

Finally, in the Table 9 it is given the SWOT analysis which presents the strengths, weaknesses, opportunities and threats for development of digital economy in Serbia. It makes it possible to recognize the positive and negative factors influencing the achievement of objectives and establishing a balance between internal capacities and external possibilities.

Table 9.: SWOT analysis of the national context

\begin{tabular}{|c|c|}
\hline $\begin{array}{l}\text { STRENGTHS } \\
\text { Good starting points for development } \\
\text { and implementation data-driven } \\
\text { economy and innovation, development } \\
\text { of cloud computing, the Internet of } \\
\text { Things and mobile technologies. } \\
\text { Examples of globally successful ICT } \\
\text { companies in niches areas (good } \\
\text { practice, networking). } \\
\text { Involvement in international cooperation } \\
\text { on projects and integration into a } \\
\text { common European educational and } \\
\text { research network } \\
\text { Established network of NGOs for } \\
\text { inclusive information society. } \\
\text { Examples of good practices in the field } \\
\text { of internet start-ups companies and the } \\
\text { use of new business models based on the } \\
\text { Internet (peer-to-peer, sharing economy, } \\
\text { cryptocurrency...). } \\
\text { Electronic communications } \\
\text { infrastructure and competitive electronic }\end{array}$ & $\begin{array}{l}\text { WEAKNESSES } \\
\text { - Significant lag in the development of } \\
\text { the information society in the last ten } \\
\text { years. } \\
\text { - Significantly too low investment in } \\
\text { information development society. } \\
\text { - Lack of development resources } \\
\text { (financial, human, material and } \\
\text { technical). } \\
\text { Too low awareness of the importance of } \\
\text { at all levels the potential of ICT for the } \\
\text { development of society. } \\
\text { Insufficient political support for } \\
\text { development efforts digital society: } \\
\text { general digitization, digital economy, } \\
\text { the introduction of e-commerce and } \\
\text { digitalisation of public sector (eg e- } \\
\text { health). } \\
\text { Declarative support is not reflected in } \\
\text { operational support support. } \\
\text { Unstable political, organizational and }\end{array}$ \\
\hline
\end{tabular}

${ }^{6}$ See: https://www.dsi.rs/postojece-pozicije-su-neodrzive/

${ }^{7}$ See: http://mtt.gov.rs/en/releases-and-announcements/serbia-is-getting-ready-for-thedigital-single-market/

Vol. 22, број 2/2020, cmp. 73-96 


\begin{tabular}{|c|c|}
\hline $\begin{array}{l}\text { communications market. } \\
\text { Digital literacy and ICT skills } \\
\text { - School-going youth are basically } \\
\text { digitally literate. } \\
\text { Wide range of formal and informal } \\
\text { education and experience in the } \\
\text { advanced use of ICT in education. } \\
\text { High level of development of e- } \\
\text { government solutions }\end{array}$ & 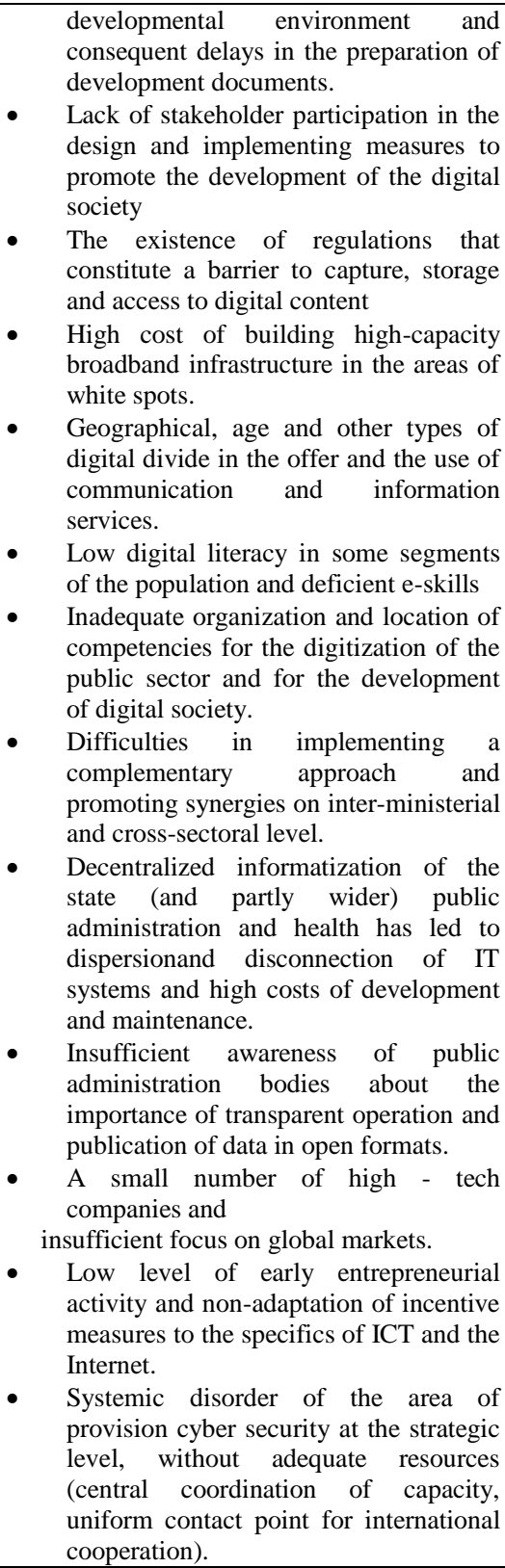 \\
\hline $\begin{array}{l}\text { OPPORTUNITIES } \\
\text { Development / test cloud computing for } \\
\text { easier and faster development of } \\
\text { innovative e-services based on open } \\
\text { public and research data and spatial data. } \\
\text { Significantly higher investments in the } \\
\text { development of the information society } \\
\text { and ICT sector. } \\
\text { Clear political support for development } \\
\text { efforts and high level of awareness of } \\
\text { importance and development } \\
\text { opportunities for ICT and the Internet. }\end{array}$ & $\begin{array}{l}\text { THREATS } \\
\text { - Insufficient awareness of the } \\
\text { importance of provision high levels of } \\
\text { cyber security. } \\
\text { Organizational and political instability } \\
\text { and insufficient sources of financing the } \\
\text { development of digitalization of } \\
\text { society. } \\
\text { Lack of understanding of the } \\
\text { development opportunities of the digital } \\
\text { society and insufficient political support } \\
\text { to provide resources to implement the }\end{array}$ \\
\hline
\end{tabular}


- Greater technological orientation of the company in directing development.

- Protecting human rights in the digital society.

- Increase efficiency through innovation and intensity use of ICT and the Internet as a horizontal strategic orientation in all development documents and activities.

- Systemic regulation of cyber security and protection of critical IT infrastructure, raising confidence in cyberspace.

- Inter - ministerial and cross - sectoral cooperation for complementary development approach and search for synergies.

- Placement of Serbia as an advanced reference environments for the introduction of new technologies (data centers, open public and research mass data, internet of things, cloud computing, IPv6...).

- New and redesigned business models based on ICT and Internet development opportunities (Industry 4.0, e-business, peer-to-peer, sharing economy).

- Research, development and establishment of open platforms,based on interoperability and standards, to facilitate and faster development of quality, innovative, safe and trusted solutions and gaining a foothold in foreign markets.

- Intensive opening of public and research data.

- Digitization of entrepreneurship and production, promotion internet entrepreneurship and internet start-ups companies.

- Development of new ways of social communication in e-form.

- Potential synergies of building smart and broadband networks and other measures to lower costs of building broadband infrastructure.

- Digitization of education and research, culture and media. Greater digital production media content.

- Consolidation and centralization of state digitalization administration using cloud computing technology and mass data, to achieve synergies

- Development of new e-services of the state administration (including health care, public sector, partly local selfgovernment) to the common service IT infrastructure.

- $\quad$ Pre - commercial public procurement of informatization and development of advanced innovative e-services of the public sector. proposed measures.

- Influence of partial interests and unwillingness to cooperation.

- Distrust of cyberspace, security and privacy and thus into the use of eservices on the Internet - impairment commercial potential of digitization and a lower rate citizens' trust in the country.

- Loss of digital cultural heritage, minor legal security and data reuse problems due to inadequate archiving and storage system of digital objects.

- Short-term and sectoral partial operation of public sector institutions

- $\quad$ Negative effects of different types of digital divide.

- $\quad$ Failure to take into account the specifics of individual target groups in digital literacy.

- Insufficient interest of stakeholders to implement the planned measures and taking advantage of digitization.

- Development lag of rural and suburban areas due to inadequate digital infrastructure.

- Deterioration of the competitiveness of the economy.

- The risk of copyright and related rights infringements due to inadequate or deficient regulations.

Source: Author,s compilation 


\section{CONCLUSION}

The modern digital economy is considered to be the leading driver of economic innovation and entrepreneurial competitiveness, and is therefore the engine of growth for both national and global economies.

The paper tries to interpret the achievements in the field of digital economy in Serbia. As a rule, Serbia is lagging behind the most developed countries, at least when it comes to the impact of the digital economy on the country's overall economic flows. It is encouraging, however, that things are slowly but surely moving from a blind spot. Transition towards the digital economy is a big development opportunity for Serbia. Serbia faces several factors which stand in the way of its digital well-being - an inadequate legal framework, poor connectivity between companies and the academic sector, the lack of private, public investments in this domain, the lack of professional staff, etc. Developing countries, such as Serbia, have a difficult but clear task to advance to a modern digital society based on the digital economy. Preparation for the Digital Single Market is especially important for our country. From investment in infrastructure and the plan for broadband Internet to arrive at every house in Serbia, through accelerated legislative adaptation to starting incubators and accelerators to start up companies and investing in them are important and necessary steps. From the point of digital transformation, the economic branches in which Serbia can achieve tremendous growth and a significant place in the world market are Agriculture and Food Industry, Automotive, Digital Entertainment, Linked Machines, Biotechnology, Data Science and Smart Infrastructure.

Serbia is still at the beginning of digitalization process in its economy and society as the speed with which we have applied and use these technologies was not high enough.

The country have not enough capabilities and capacity to: realize the real impact of ICT implementation on transformation its economy and society, use ICT potentials in order to enable sustainable economic growth and improve the business quality of domestic enterprises. Serbia has the basement for DE development but infrastructure, organization and human resource frameworks have to be further improved in order to enable domestic enterprises to do their business more competitive through the ICT use and national economy to realize long-term dynamic economic growth. Important tasks on the transformation road to digitally driven economy are: 1 . increase industry digital transformation; 2 . create a digital entrepreneurial culture; 3. attract, develop and retain high-end digital skills and talent; 4. ease the access to finance and enhance investments and boost the digitally powered market. 


\section{REFERENCES}

1. Abraham K., Haltiwanger, J., Sandusky, K., \& Spletzer, J. (2017), Measuring the Gig Economy: Current Knowledge and Open Issues, available http://conference.iza.org/conference_files/Statistic_2017/abraham _k16798.pdf (Accessed on 25 March 2020).

2. Afonasova, M.A., Panfilova, E.E., Galichkina, M.A. (2018). Social and Economic Background of Digital Economy: Conditions for Transition, European Research Studies Journal, 21(3), 292302.

3. Bukht, R \& Heeks, R. (2018). Defining, Conceptualising and Measuring the Digital Economy, International Organisations Research Journal, 13(2), 143-172.

4. Bukht, R. \& Heeks, R. (2017). Defining, Conceptualising and Measuring the Digital Economy, Working Paper Series, Paper No. 68, Centre for Development Informatics Global Development Institute, SEED University of Manchester, Arthur Lewis Building, Manchester, M13 9PL, UK.

5. Cornell University, INSEAD \& WIPO (2017): The Global Innovation Index 2017: Innovation Feeding the World, Ithaca, Fontainebleau, and Geneva.

6. Cornell University, INSEAD \& WIPO (2018). The Global Innovation Index 2018: Energizing the World with Innovation, Ithaca, Fontainebleau, and Geneva, Retrieved from: https://www.wipo.int/edocs/pubdocs/en/wipo_pub_gii_2018.pdf (Accessed on: 15 October 2018).

7. Devezas, T., Leitão, J. \& Sarygulov, A. (2017). Industry 4.0 Entrepreneurship and Structural Change in the New Digital Landscape (Springer International Publishing, Cham, 2017).

8. Digital Serbia. (2017). Digitalni manifest [Digital manifest].Beograd: Digital Serbia.

9. Đuričin, D., \& Vuksanović-Herceg, I. (2018). Digital Serbia: Economic context adjustments for double GDP. Ekonomika preduzeća, 66(1-2), 19-41.

10. European Commission (2018a). Digital Economy and Society Index (DESI) 2018. European Commission - Fact Sheet, Brussels, 18 May 2018, Questions and Answers.

11. European Commission (2018b). International Digital Economy and Society Index 2018, SMART 2017/0052, FINAL REPORT, European Union, 2018, ISBN 978-92-79-85699-0 
12. European Commission (2018c). Press release: European Commission launches Digital Agenda for the Western Balkans. Brussels, 25 June 2018, Retrieved from: http://europa.eu/rapid/press-release_IP-18-4242_en.htm (Accessed on: 10 November 2018).

13. European Union (2015). Ten priorities for Europe. A new start for Europe: an EU agenda for jobs, growth, fairness and democratic change. Luxembourg: Publications Office of the European Union, 2015, Retrieved from: https://eeas.europa.eu/sites/eeas/files/tenpriorities-for-europe.pdf (Accessed on: 5 October 2018).

14. Goldfarb, A., \& Tucker, C. (2019). Digital Economics, Journal of Economic Literature, 57(1), 3-43.

15. Guo, S., Ding, W., \& Lanshina, T. (2017). Digital Economy for Sustainable Economic Growth. International organizations research journal, 12(4), 169-184.

16. http://mtt.gov.rs/en/releases-and-announcements/serbia-is-gettingready-for-the-digital-single-market/ (Accessed on: 15 October 2018).

17. https://ec.europa.eu/digital-single-market/en/desi (Accessed on: 15 October 2019).

18. https://www.dsi.rs/postojece-pozicije-su-neodrzive/ (Accessed on: 15 October 2018).

19. Izveštaj Svetske banke, Informacija i komunikacija za razvoj 2009: proširenje dostupnosti i povećanje uticaja, 2009.

20. Kupriyanovsky, V. P., Sinyagov, S. A., Lipatov, S. I., Namiot, D. E., \& Vorobiev, A. O. (2016). Digital Economy-Smart Working. International Journal of Open Information Technologies, 4(2), 26-33.

21. Mărcuţ, M. (2017). Crystalizing the EU digital policy: An exploration into the digital single market. Springer International Publishing.

22. Mayer, J. (2018). Digitalization and industrialization: friends or foes?, UNCTAD Research Paper No. 25, available at: https://unctad.org/en/PublicationsLibrary/ser-rp-2018d7_en.pdf (Accessed. 20 March 2020).

23. Mitrović, Đ. (2017). Na putu ka blagostanju 4.0-Digitalizacija u Srbiji. Izveštaj analize Freidrich Ebert Stiftung. Beograd.

24. OECD (2016). OECD Observer: The Digital Economy, OECD, Paris.

25. OECD. (2015). Measuring the Digital Economy A New Perspective. OECD Publishing. 
26. Portulans Institute (2019): Network Readiness Index 2019, Washington D.C., USA. Available at: https://networkreadinessindex.org/wpcontent/uploads/2020/03/The-Network-Readiness-Index-2019New-version-March-2020-2.pdf (Accessed on: 15 February 2019).

27. Schallmo, D. R., Williams, C. A. (2018). History of Digital Transformation, Digital Transformation Now! pp. 3-8. Springer, Cham. doi: 10.1007/978-3-319-72844-5_2.

28. Spalević, Ž., Vićentijević, K., \& Ateljević, M. (2018). Pravnoekonomska analiza stepena razvoja digitalne ekonomije. Trendovi u poslovanju, 6(11), 29-38.

29. Strategija razvoja informacionog društva u Republici Srbiji do 2020. godine, Službeni Glasnik Republike Srbije br. 5/2010, 2010, available at:

http://paragraf.rs/propisi/strategija_razvoja_informacionog_drustv a_u_republici_srbiji.html (Accessed on: 15 October 2019).

30. The Digital Economy and the Green Economy: Opportunities for strategic synergies, An IISD Commentary, July 2010, Retrieved from: https://www.iisd.org/pdf/2010/com_digital_economy.pdf (Accessed on: 7 November 2018).

31. Unold, J. (2003) Basic Aspects of the Digital Economy. Acta Universitatis Lodziensis, Folia Oeconomica, 167, 2003, 41-49.

32. Van Ark, B. 2016. The Productivity Paradox of the New Digital Economy, International Productivity Monitor, 31, 3-18.

33. WEF (2015). Expanding Participation and Boosting Growth: The Infrastructure Needs of the Digital Economy, World Economic Forum, Geneva, www3.weforum.org/docs/WEFUSA_DigitalInfrastructure_Report 2015.pdf

34. World Bank (2016). World Development Report 2016: Digital Dividends. Washington, DC: World Bank. doi:10.1596/978-14648-0671-1.

35. World Economic Forum (2018). Readiness for the Future of Production Report 2018. 2018 World Economic Forum, CH-1223 Cologny/Geneva, Switzerland, Retrieved from: http://wef.ch/fopreadiness18 (Accessed on: 29 October 2018).

36. WORLD ECONOMIC FORUM (2019). The Global Competitiveness Report 2019. World Economic Forum, Geneva

37. Zysman J. \& Kenney, M. (2018). The Next Phase in the Digital Revolution: Abundant Computing, Platforms, Growth, and Employment, Communications of the Association of Computing Machinery, 61(2), 54-63. 
38. Републички завод за статистику (RZS) (2017). Статистички годишњак Републике Србије [Statistical Yearbook of the Republic of Serbia]. Република Србија - Републички завод за статистику, Београд/Belgrade 2017.

Рад је примљен: 21.05.2020.

Коригована верзија рада је примљена: 10.07.2020.

Рад је прихваћен за итампу: 13.07.2020. 